\title{
Autosomal recessive sideroblastic anemia
}

INSERM

\section{Source}

INSERM. (1999). Orphanet: an online rare disease and orphan drug data base. Autosomal recessive sideroblastic anemia. ORPHA:260305

Congenital autosomal recessive sideroblastic anemia (ARSA) is a non-syndromic, microcytic/hypochromic sideroblastic anemia, present from early infancy and characterized by severe microcytic anemia, which is not pyridoxine responsive, and increased serum ferritin. 